\section{Close encounter in the deep}

SIR - Benthic octopodids are cosmopolitan marine predators that have been reported to occur to depths of almost $4,000 \mathrm{~m}$ (ref. 1), yet in situ observations of the animals in deep-sea environments have been extraordinarily rare. In Decem-

small male subsequently succeeded in introducing the distal end of his hectocotylus into the mantle cavity of the large male (see figure), an act constituting copulation in octopodids ${ }^{3}$.

Ventilation rate, which is argued to

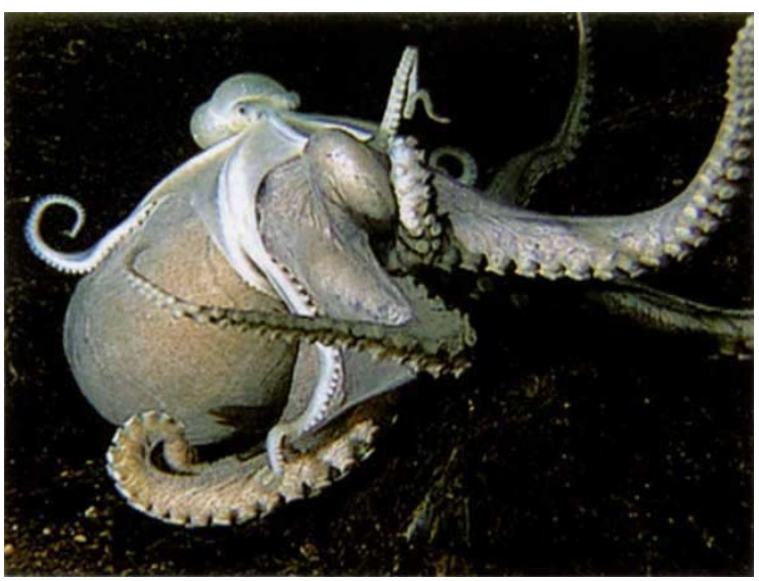

Two incirrate octopods engaged in copulatory behaviour at a depth of 2,512 $\mathrm{m}$ along the crest of the East Pacific Rise. Both individuals have a hectocotylus, a uniquely male copulatory arm. Differences between their hectocotyli, the texture, colour and degree of transparency of their skin, shape of their heads and eyes, and robustness of their arms and bodies, unambiguously identify the two individuals as males of distinct octopodid species; neither individual can be assigned to a previously described species. The right ventrolateral arm (hectocotylus) of the small male extends into the mantle cavity of the large individual. The mantle length of the small male is approximately $8 \mathrm{~cm}$. The video print is one frame of a 16-min sequence filmed using externally mounted, 400-watt HMI (mercury, metallic, iodide) lights and a high-resolution, 3-chip camera linked to a Beta video recording system on the deep-diving submersible Alvin. Video image produced by $A$. Giddings, E. Kristof, W. Lange, R. Grieve and R. L.

ber 1993, the deep-diving submersible Alvin, while traversing expansive lava sheet flows on the floor of the axial summit caldera of the East Pacific Rise at $9^{\circ} 50^{\prime} \mathrm{N}(\text { depth } 2,512 \mathrm{~m})^{2}$, encountered two males of distinct octopodid species engaged in copulatory behaviour (see figure). Behavioural patterns of the two octopods were documented over a 16minute period using a high-resolution, 3-chip camera; the Beta videotape record is the basis for observations reported here.

During the 16-minute video sequence, the small male shifted from his initial transverse orientation to a more parallel position relative to the large male. When observations began, the hectocotylus of the small male was near the left side of the large male's mantle aperture. As the small male shifted position, his hectocotylus moved across the posterior dorsal surface of the large male's mantle; his ligula (intromittent organ), in contrast to its normal, protected position, became extended. After the shift in position, his hectocotylus was brought anteriorly to the large male's right mantle aperture. The reflect alteration of behavioural states in octopodids $^{4}$, was monitored in the small male throughout the 16-minute video sequence. During the initial 10 minutes, ventilation by this individual was virtually undetectable. During the last 6 minutes of observation, the small male vigorously ventilated his mantle 7-9 times each minute. It was during the latter period that his ligula became extended and his hectocotylus entered the mantle aperture of the large male.

The present study, to our knowledge the first account of copulatory behaviour in deep-water octopods, questions whether copulation between males of different species of these mobile abyssal organisms is a rare event. The apparent readiness to copulate, or attempt to copulate, may reflect adaptations to low mate availability and the short lifespan of cephalopods, a group in which promiscuous mating occurs ${ }^{3}$. Although females can increase their fitness by mating with older males (those with a proven ability to survive to an advanced age $)^{5}$, males are fully mature for a relatively brief period before senescence ${ }^{3}$. The fitness of mature males carrying accrued spermatophores is limited by the time remaining in their lifespans and by the number of mates they encounter. Among shallowwater octopuses, mature males are more mobile than immature individuals, increasing their likelihood of encountering mates $^{6}$. Where mates are few, such as in the low-density, heavily fragmented populations of the deep sea, high mobility may not be sufficient to increase male fitness. In such environments, males may further modify their behaviour to increase the time, energy and possibly gametes

2. Haymon, R. et al. Earth planet. Sci. Lett. 104, 513-534 (1991); 119, 85-101 (1993).

3. Mangold, K. in Cephalopod Life Cycles Vol. 2 (ed. Boyle, P R.) 157-200 (Academic, London, 1988).

4. Boyle, P. R. J. exp. mar. Biol. Ecol. 69, 129-136 (1983)

5. Halliday, T. R. in Mate Choice (ed. Bateson, P.) 3-32 (Cambridge Univ. Press, UK, 1983)

6. Voight, J. R. J. Zool., Lond. 228, 247-263 (1992).
1. Voss, G. L. Malacologia 29, 295-307 (1988). invested in each encounter with another octopod rather than to leave opportunities for reproduction unexplored.

\section{Richard A. Lutz}

Department of Marine and Coastal

Sciences,

Rutgers University,

New Brunswick, New Jersey 08903, USA

Janet R. Volght

Department of Zoology,

The Field Museum of Natural History,

Roosevelt Road at Lake Shore Drive,

Chicago, Illinois 60605, USA

\section{Preventing hair loss in mice}

SIR - We wish to report the successful transfer to mice of two genes, cysE and cys $K$, from Escherichia coli which encode the enzymes necessary for the assimilation of inorganic sulphide for the biosynthesis of the amino-acid cysteine ${ }^{1,2}$. These mice are able to synthesize cysteine when supplemented with $\mathrm{Na}_{2} \mathrm{~S}$, and the effect of dietary sulphur amino-acid deprivation on hair growth is prevented. Our results demonstrate that the introduced biochemical pathway is functional and

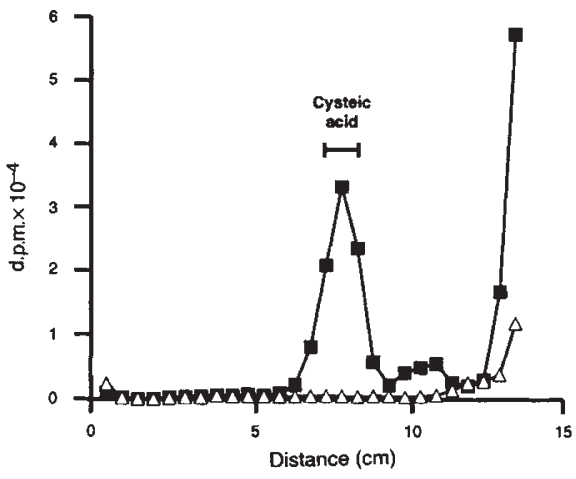

FIG. 1 Biosynthesis of cysteine (measured as cysteic acid) from $\mathrm{Na}_{2}{ }^{35} \mathrm{~S}$ in vitro in intestinal tissue isolated from transgenic mice containing the gene MTCEK1. Transgenic, filled squares; control, triangles.

establishes the principle implicit in the pioneering research of Palmiter et $a .^{3,4}$; that the modification of animal biochemistry is feasible by the transfer of functional genes from bacteria or other sources in nature.

\footnotetext{
1. Denk, D. \& Bock, A. J. gen. Microbiol. 133, 515-525 (1987).

2. Byrne, C. R., Monroe, R. S., Ward, K. A. \& Kredich, N. M J. Bact. 170, 3150-3157 (1988)

3. Palmiter, R. D. etal. Nature 300,611-615 (1982)

4. Palmiter, R. D., Norstedt, R. E., Gelinas, R. E., Hammer, R. E. \& Brinster, R. L. Science 222, $809-814$ (1983) 5. Leish, Z., Byrne, C. R., Hunt, C. L. \& Ward, K. A. Appl. Environ. Microbiol. 59, 892-898 (1993)

6. Hogan, B., Costantini, F. \& Lacy, E. Manipulating the Mouse Embryo. A Laboratory Manual (Cold Spring Harbor Laboratory, New York, 1986).

7. Huovinen, J. A. \& Gustafsson, B. E. Biochim. biophys. Acto 136, 441-447 (1967)

8. Leveille, G. A., Sauberlich, H. E. \& Shockley, J. W. J. Nutr. 75, 455-458 (1961)
} 